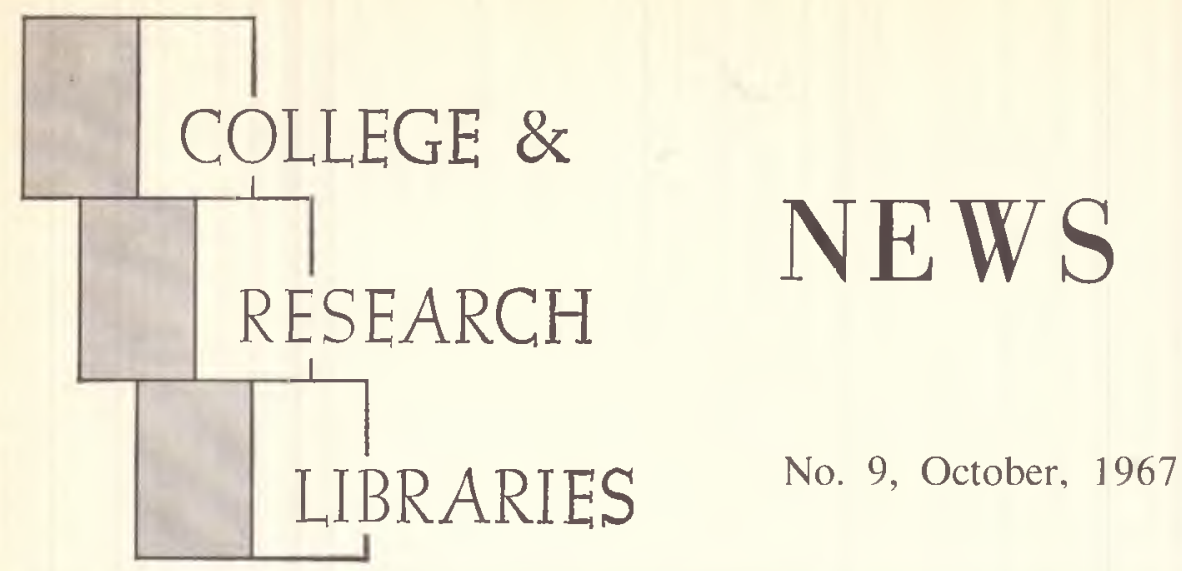

ACRL News Issue (B) of College \& Research Libraries, Vol. 28, No. 5

\title{
The Council on Library Resources and CHOICE: An Appreciation
}

EARLIER THIS YEAR the ACRL Board of Directors approved the following resolution, which was transmitted to the Council on Library Resources.

Whereas the Council on Library Resources has granted a second subsidy of $\$ 108,855$ to provide for the continuing publication of CHOICE, be it resolved that the Board of Directors of the Association of College and Research Libraries expresses its deep gratitude to the Council on Library Resources for its generous and timely support.

The following is an extended statement of appreciation from the ACRL Board of Directors which also has been forwarded to the Council:

The first issue of CHOICE, the book review journal issued by ACRL, was published in March 1964 at Middletown, Conn., five years after the idea was first conceived. The elapsed time between conception and finished product was due to exhaustive planning, interviewing, and revising by two prime movers: Verner Clapp, president of the Council on Library Resources, and his colleague, Robert Jordan.

Mr. Clapp realized in 1959, along with many fellow librarians, that the "Shaw List" desperately needed updating. He was not satisfied merely to print a list of arbitrary titles. Such a list, although an easy task given sufficient financial support, would soon be out-of-date. One piece of evidence supporting this foresight is the fact that annual book production in the United States has more than doubled since 1959-from 14,000 to 30,000 . More useful to academic libraries would be a periodical that reviewed and evaluated books as they were published, keeping in mind the need of the college library. Such a work would utilize subject specialists and would publish evaluations via a printing method that would permit storage and re-use of full information, namely, magnetic tapes. With these ideas in mind, two dependent operations followed: (1) interviewing of members of the library profession to elicit their opinions on a "New Shaw"; and (2) finding an organization willing to sponsor the operation on a continuing basis. The interviews developed into meetings, conferences, and idea sessions. This time-consuming assessment of opinion achieved its purpose in establishing the kind of book list college librarians wanted. Much pulling, pushing, and coordinating by the Council on Library Resources resulted in a detailed draft of the 


\section{Taylor-Carlisle}

Booksellers to the Academic World

\section{Another exclusive TAYLOR-CARLISLE}

\section{service}

In order to accommodate our customers, we have increased our inventory of John Wiley \& Sons titles fourfold. Wiley is moving their warehouse and will be temporarily unable to meet normal shipping demands.

We suggest you take advantage of our strong position in this area.
Liberal terms

.. send for our current discount schedule

\section{Efficient service}

.. . alert, experienced personnel

\section{Huge inventory}

... in our own warehouses

Speedy delivery

. . your order processed without delay

\section{Taylor - Carlisle}

NEW YORK: 115 East 23rd Street

New York, N.Y. 10010

FLORIDA: Winter Park Mall

Winter Park, Florida 
"New Shaw." It was to be a book review periodical with consultants, managed by an editor with a permanent staff. Its purpose was to evaluate current books of a scholarly or academic nature. The entire operation of the proposed periodical was now down on paper. There remained the need to find an organization to sponsor the project.

The American Library Association, specifically its Association of College and Research Libraries, seemed to be the most appropriate publisher. A proposal for joint sponsorship by the Council and the American Library Association was wisely rejected by Mr. Clapp and David H. Clift, executive director of the American Library Association. After an agreement was reached between ACRL's Board of Directors and ALA over the duties of the editor, the new periodical became a responsibility of the ACRL

Considerable financial backing was needed to launch a periodical of this magnitude and the American Library Association applied to the Council on Library Resources for a grant with which to underwrite the project. In 1961, upon the recommendation of $\mathrm{Mr}$. Clapp, the Council granted the new reviewing journal $\$ 150,000$.

Two years passed before an editor was appointed, during which time academic libraries were faced with three forces of growth: book publishing, book budgets, and student enrollment. The patience and faith of the Council on Library Resources during this delay was admirable. In 1963, Richard K. Gardner became the first editor and a staff was assembled.

March 1964 saw the appearance of Volume I, Number 1, of CHOICE. In the three years that have passed Verner Clapp and the Council on Library Resources have seen their idea mature into a valuable aid in developing library collections. In three volumes, CHOICE, with its over two thousand subject specialists, has offered succinct, comparative reviews of scholarly books $(5,400$ in Volume III), has assisted in the selection of consultants for Books for College Libraries, has published (Continued on page 230)

ACRL Membership, August 31, 1967

12,060

August 31, 1966

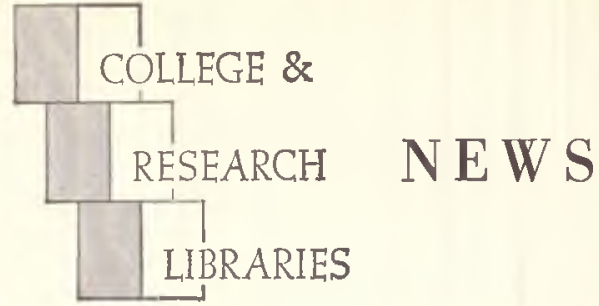

ACRL News Issue of College \& Research Libraries

Editor, David Kaser, Joint University Libraries, Nashville, Tenn. 37203.

Publications Officer, Mary Falvey, $50 \mathrm{E}$. Huron St., Chicago 60611.

ACRL Executive Secretary, George M. Bailey.

ACRL Officers, 1967/68: President, James Humphry III; College Libraries Section Chairman, Audrey North; Junior College Libraries Section, Mrs. Alice B. Griffith; Rare Books Section, Lawrence S. Thompson; Subject Specialists Section, Richard L. Snyder; Agriculture and Biological Sciences Subsection, Mrs. Pauline W. Jennings; Art Subsection, James K. Dickson; Law and Political Science Subsection, Morris Cohen; Slavic and East European Subsection, Jerzy (George) J. Maciuszko; University Libraries Section, Stuart Forth.

Editorial Board: John M. Dawson, University of Delaware; Gustave A. Harrer, Boston University; SamUEL RothstenN, University of British Columbia; James E. Skipper, Princeton University; Norman E. Tanis, Kansas State College of Pittsburg; Maurice F, Tauber, Columbia University; Eileen Thonnton, Oberlin College.

News from the Field, Personnel profiles and notes, classified advertising, official matter of ACRL, anc other material of a timely nature is published in the Nervs issues of College \& Research Libraries.

Inclusion of an article or advertisement in CRL does not constitute official endorsement by ACRL or ALA.

Production and Advertising and Circulation office: $\mathbf{5 0}$ E. Huron St., Chicago, Ill. 60611. Change of address and orders for subscriptions should be addressed to College of Research Libraries, for receipt at the above address, at least two months before the publication date of the effective issue.

Subscription to $C R L$ is included in membership dues to $A C R L$ of $\$ 6$ or more; other subscriptions to $C R L$ are $\$ 10$ per year. Neither subscriptions nor memberships include miscellaneous unscheduled supplements, which are available by purchase only. Retroactive subscriptions are not accepted. Single journal copies are available at $\$ 1.50$ each and News issues at $\$ 1.00$ each from ALA Publishing Department.

Indexed in Library Literature. Abstracted in Library Science Abstracts. Book reviews indexed in Book Review Index.

College of Research Libraries, is the official journal of the Association of College and Research Libraries, division of the American Library Association; and is published seventeen times per year-bi-monthly as a technical journal with 11 monthly News issues, combining July-August-at 1201-05 Bluff St, Fulton, Mo. 65251 .

Second-class postage paid at Fulton, Mo. and at additional mailing offices. 
cation, and price per issue or per annum. Available at $\$ 15$ net postpaid, from R. R. Bowker Company, 1180 Avenue of the Americas, New York, N.Y. 10036.

\section{SUGGESTIONS, ANYONE?}

The ACRL Committee on Appointments (1968) and Nominations (1969) wishes to solicit suggestions for appointments to ACRL committees for 1968/69. ACRL's success or failure during the year will depend to a large extent on these appointments.

Therefore, we urge you to submit the names of members who would make significant contributions to the work of ACRL through committee appointment. As the number of appointments to be made is limited, it is important that the best possible appointments be made.

Members of the Committee on Appointments (1968) and Nominations (1969) include Ben C. Bowman, Jane G. Flener, Harriett Genung, Marcus A. McCorison, Carl H. Sachtleben, Mrs. Jessie Carney Smith and Howard Rovelstad, chairman.

Kindly send your recommendations of prospective appointees to the following ACRL committees to the undersigned:

Join the

AMERICAN LIBRARY ASSOCIATION

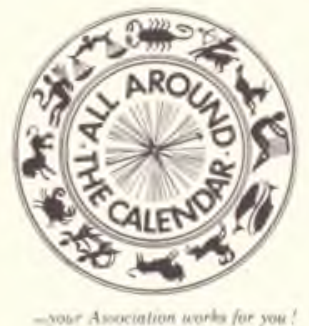

MeMachaหir pMomotion MMCRICAN LIERART ASSOCBATION So CAST HUaON STREeT
Audio-Visual Committee

Committee on Community Use of Academic Libraries

Advisory Committee on Cooperation with Educational and Professional Organizations

Committee on Grants

International Relations Committee

Committee on Legislation

Committee on Liaison with Accrediting Agencies

Committee on Library Services

Committee on Library Surveys

National Library Week Committee

Planning and Action Committee

Publications Committee

Committee on Standards

Recommendations should be sent to the undersigned by November 15 .

Howard Rovelstad, Chairman

ACRL Committee on Appointments (1968) and Nominations (1969)

University of Maryland Libraries College Park, Maryland 20740

\section{AN APPRECIATION \\ (Continued from page 223)}

subject-centered bibliographic articles, has contributed such selection aids as the "Opening Day Collection," and, according to the response from subscribers, has filled a void in current reviewing of academic books. It has proved useful to public, junior college, secondary school, special, and foreign libraries.

CHOICE promises to provide continuing evaluation of new books; but it is also considering the publication of supplements to Books for College Libraries, and is moving toward reviewing U.S. Government documents and foreign publications.

CHOICE is essentially the product of the intelligence, determination, and courage of Verner Clapp and members of the Council on Library Resources. Because of their support and advice, librarians and libraries are benefiting. Both the Council and Verner Clapp have eschewed interference with editorial policy, placing confidence in the Association of College and Research Libraries, which in turn, has intrusted the policy-making to an editorial board. The Association appreciates the Council's further commitment to CHOICE in the form of a three-year grant renewal for $\$ 108,855$. Such confidence merits increased service to libraries by the Association and the editorial staff of CHOICE. 